\title{
LA CONFORMACIÓN DE UN ICONO GENÉRICO Y SU CONTEXTO: AUGUSTO CÉSAR SANDINO Y LA OPINIÓN PÚBLICA ESPAÑOLA (1928-1934)
}

\author{
THE CONFORMATION OF A GENERIC ICON AND HIS CONTEXT: \\ AUGUSTO CÉSAR SANDINO AND THE SPANISH PUBLIC OPINION
}

(1928-1934)

Manuel Andrés García*

Universidad de Huelva, España.

RESUMEN: El objetivo de este artículo es la revisión de la figura de Augusto César Sandino y su impacto sociopolítico en la opinión pública española. Partiendo de un análisis de los acontecimientos que impulsaron la figura del líder guerrillero a la escena internacional, examinaremos la repercusión de sus actuaciones dentro de una coyuntura intervencionista como la planteada por los Estados Unidos en Centroamérica y el Caribe en las primeras décadas del xx, al igual que la reacción de los países hispanohablantes respecto a las injerencias de Washington. Será a partir de dicho contexto que abordaremos la repercusión de Sandino en la intelectualidad y medios peninsulares, tomando como referencia diarios de todo el arco ideológico para confirmar cómo, aun desde perspectivas diferenciadas $-\mathrm{y}$ en un marco temporal de apenas siete años - el nicaragüense acabaría convertido en un icono compartido, pero de disímil significación.

PALABRAS CLAVE: Hispanoamericanismo; Antiimperialismo; Augusto César Sandino; Iconología política; Relaciones España-EE.UU-Latinoamérica; siglo Xx.

ABSTRACT: The objective of this article is the revision of the figure of Augusto César Sandino and its sociopolitical impact on the Spanish public opinion. Starting from an analysis of the events that drove the figure of the guerrilla leader to the international arena, we will examine the impact of his actions within an interventionist moment as posed by the United States in Central America and the Caribbean in the first decades of the Twentieth century, as well as the reaction of the Spanish-speaking countries regarding the interference of Washington. It will be from the above mentioned context that the repercussion of Sandino on the intellectuality and peninsular media will be addressed, taking as reference the newspapers of the entire ideological arch to confirm how, even from different perspectives - and within a timeframe of just seven years - the Nicaraguan would eventually become a shared icon, but of dissimilar significance.

KEYWORDS: Hispanic-Americanism; Anti-imperialism; Augusto César Sandino; Political iconology; Spain - USA - Latin America relationships; Twentieth century.

* Correspondencia a: Manuel Andrés García. Universidad de Huelva. Departamento de Historia, Geografía y Antropología. Facultad de Humanidades. Avda. Tres de Marzo, s/n. 21071 Huelva (Spain) - manuel.andres@dhis2.uhu.es - https:// orcid.org/0000-0001-8771-8653

Cómo citar: Andrés García, Manuel (2020). "La conformación de un icono genérico y su contexto: Augusto César Sandino y la opinión pública española (1928-1934)»; Historia Contemporánea, 64, 919-952. (https://doi.org/10.1387/hc.20510).

Recibido: 10 enero, 2019; aceptado: 28 junio, 2019.

ISSN 1130-2402 - eISSN 2340-0277 / (C) 2020 UPV/EHU

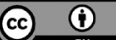

Esta obra está bajo una licencia

Creative Commons Atribución 4.0 Internacional 
El 23 de febrero de 1934 las redacciones de los principales diarios se vieron sorprendidas por una noticia que conmocionó a la opinión pública internacional y, muy en particular, a la hispanoamericana: el asesinato de Augusto César Sandino. Un crimen cuya repercusión trascendería toda ideología para hacerse patente, en términos de reconocimiento o de indignación, en periódicos tan dispares como el conservador $A B C$, el liberal El Sol o el izquierdista La Libertad.

La trascendencia mediática de Sandino hay que insertarla en un contexto global de efervescencia política e ideológica que, en lo que a Latinoamérica se refiere, estaría acentuada por el intervencionismo norteamericano. Sólo así se explica la notoriedad cobrada por quien, apenas seis años antes, era un completo desconocido y, del mismo modo, sólo partiendo de ese punto puede entenderse la lectura apologética que de su trayectoria haría la intelectualidad continental, elevándolo prácticamente a la condición de mito.

En España las hazañas del nicaragüense caerían en terreno abonado para su exaltación. Tal actitud se alimentaría, en buena parte, de la extendida animadversión que se respiraba en la Península hacia los Estados Unidos. Una aversión que, si bien se había ido forjando desde la independencia de las Trece Colonias ${ }^{1}$, encontró su culminación en 1898, con un Tratado de París que despojó a España de sus últimos territorios en Ultramar y la relegó al vagón de cola de las potencias occidentales. Fue así como las posteriores injerencias norteamericanas al sur de sus fronteras encontraron en la opinión pública española un ambiente refractario, impulsado por un hispanoamericanismo siempre dispuesto a acompañar las censuras al expansionismo de Washington con el aplauso a sus opositores.

La intención de este trabajo es, precisamente, analizar el impacto que supuso la figura de Sandino en la prensa española, así como constatar la participación de ésta en el enaltecimiento del nicaragüense con independencia de la línea editorial. Para ello haremos una prospectiva sobre el

${ }^{1}$ No pretendemos con ello obviar el apoyo español a la independencia estadounidense, sino recalcar cómo lo que fue una decisión de conveniencia para debilitar a los británicos acabó elevando a la condición de adversario a los beneficiarios de la ayuda, de manera tal que, si a nivel oficial la relación entre Madrid y Washington pareció empezar con buen pie, en el ámbito ideológico y geopolítico no demoraría en mostrar sus primeras grietas. Profético resultaría a este respecto la memoria secreta remitida en 1783 por el Conde de Aranda, embajador español en París, a Carlos III, advirtiendo cómo ese «pigmeo» que habían ayudado a crear terminaría siendo un «gigante» y cómo «dentro de algunos años veremos con verdadero dolor la existencia tiránica de este coloso de que hablo». Fernández, 2012, 15. 
tratamiento dispensado al guerrillero en los medios peninsulares, tomando como referencia rotativos de tendencias opuestas como los ya citados $A B C$ o La Libertad y en un arco temporal de apenas siete años, justo aquellos en los que se forjó la imagen de Sandino como icono antiimperialista: de 1928 a 1934. Un periplo convulso, internacionalmente hablando, tanto en lo político como en lo económico. Y un septenio de transición y cambio en España que, con la caída del Directorio y el advenimiento de la II República, también tendría sus efectos en el asunto que nos ocupa.

\section{Panamericanismo e hispanoamericanismo en las relaciones entre España, Estados Unidos y la América Hispana}

Las relaciones hispano-estadounidenses ha sido un tema tradicionalmente soslayado por la historiografía española, no siendo hasta hace apenas unas décadas que comenzaron a proliferar monografías, artículos y trabajos colectivos sobre dicha cuestión. Pablo León Aguinaga señala el 2003 como un año clave a este respecto, tanto por su carácter simbólico $^{2}$ como por ser en éste que vio la luz un dossier que considera clave en el cambio de rumbo historiográfico: «50 años de relaciones entre España y los Estados Unidos» ${ }^{3}$, coordinado por Antonio Niño y publicado por Cuadernos de Historia Contemporánea. Cierto es que tal afirmación pudiera parecer desdeñosa respecto a quienes, con anterioridad, ya habían señalado la importancia del asunto - ya fuese de manera puntual o continuada - pese al aparente desinterés general. Nos referimos a gente como Manuel Azcárate, Antonio Ñ́guez Bernal o aquellos autores que, desde el hispanismo norteamericano, ilustraron distintos aspectos del bilateralismo hispano-estadounidense. Sin embargo, una retrospectiva historiográfica revela la particular incidencia que en los últimos años han tenido, por ejemplo, los estudios sobre el conflicto de 1898 y sus repercusiones; o los dedicados a la participación norteamericana - de manera exenta o inserta en una perspectiva internacional - en la Guerra Civil Española;... por no hablar de los trabajos, cada vez más profusos, sobre la presencia e influencia españolas en territorios pertenecientes, en la actualidad, a los Estados Unidos.

2 Ese año se conmemoraba el 50 aniversario del Pacto de Madrid.

3 Niño, 2003. 
No es éste un artículo dirigido a enfocar las relaciones diplomáticas hispano-estadounidenses, bien escrutadas en nuestro país por José Antonio Montero o Sylvia Hilton, entre otros, y que escapan al propósito de este trabajo ${ }^{4}$. Sin embargo, sí indagaremos en un periodo particularmente interesante en cuanto a connivencias y desencuentros entre Madrid y Washington: el comprendido entre 1898 y 1936. Entre una conflagración que quebró el espejismo imperial español y otra que acabó sumiendo al país en un choque de antagonismos que no tardaría en reeditarse a escala mundial.

Fue durante este periplo que las dudas sobre la españolidad y su idiosincrasia vendrían acompañadas, paradójicamente, de un acercamiento entre esa España en crisis y las repúblicas hispanoamericanas. Ya con motivo de las conmemoraciones del IV Centenario se había producido cierta aproximación entre la antaño metrópoli y sus antiguas colonias, pero fue tras la derrota ante los Estados Unidos que se confirmó un cambio, dentro del imaginario hispanoamericano, en el que la nueva potencia emergente confirmaría su posición hegemónica dentro del continente y, con ella, su naturaleza bifronte: por un lado, como modelo de desarrollo político y económico; por el otro, como amenaza más que previsible para la soberanía de sus vecinos 5 .

${ }^{4}$ Montero dirigió un interesante dossier en 2012 para la revista Circunstancia bajo el título «España y Estados Unidos (1877-1975). El largo camino hacia la normalización de las relaciones bilaterales». Aparte, es muy recomendable su obra El despertar de la gran potencia. Las relaciones entre España y los Estados Unidos (1898-1930). En cuanto a Hilton, una magnífica introducción para conocer el devenir de las relaciones culturales hispano-estadounidenses sería el dossier que coordinó en 2010 para la Revista Complutense de Historia de América bajo el título «Relaciones históricas hispano-estadounidenses: visiones del siglo Xx en clave cultural». Para un mayor conocimiento del impacto que tuvo en los medios españoles la retórica monroísta o la interpretación que estos harían de la misma desde 1895, es muy recomendable su artículo «La «nueva» Doctrina Monroe de 1895 y sus implicaciones para el Caribe español: algunas interpretaciones coetáneas españolas».

${ }^{5}$ Esta visión disociada también podemos encontrarla, con matices diferenciados, en la propia España, donde el rechazo a los Estados Unidos y su política exterior encontró amplio acomodo en la prensa y la intelectualidad coetáneas pero, a la par, también se asumiría su poderío económico y los beneficios potenciales de su comercio. Esto produciría situaciones ambivalentes en las que los prejuicios mutuos irían de la mano de unas relaciones comerciales no siempre fáciles, por no hablar de las frecuentes discrepancias en cuanto a la América Hispana y su futuro. Ver Montero, 2011. Un artículo interesante para observar las suspicacias norteamericanas respecto a España y los españoles durante el Directorio es Montero, 2010. 
Este cambio de actitud cabe contemplarlo dentro de un marco de confrontación ideológica como el que sostuvieron panamericanismo e hispanoamericanismo. Dos discursos que, con América Latina como trasfondo, encarnarían sendas visiones antagónicas sobre lo que debían ser las relaciones interamericanas, sus objetivos y fundamentos. Con todo, un análisis pormenorizado de ambas doctrinas revela, por una parte, su heterogeneidad y, por otra, un complejo juego de intereses en el que igual cabrían la versión económica, comercial y financiera del expansionismo norteamericano que la consolidación del antiimperialismo como corriente de pensamiento. O, desde otro punto de vista, las variadas propuestas de unidad continental y los esfuerzos de la diplomacia e intelectualidad españolas por arrogar a España el liderazgo, más simbólico que real, de la comunidad hispanohablante.

El panamericanismo daría muestras de su naturaleza injerencista prácticamente desde sus comienzos. Baste recordar los recelos de las legaciones latinoamericanas en la primera gran celebración panamericanista ${ }^{6}$, ante las propuestas del entonces Secretario de Estado norteamericano, James Blaine, respecto a la impulsión de una posible unión aduanera o la creación de un tribunal de arbitraje de carácter continental. La desconfianza latinoamericana estaba bien fundada: en lo concerniente a la unión aduanera, por el perjuicio que una zona comercial exclusivamente americana podía causar a sus relaciones con una Europa cuyas inversiones, en esos momentos, eran determinantes ${ }^{7}$; en lo tocante a la implementación de un tribunal interamericano, las suspicacias iniciales se acabarían confirmando conforme fue desvelándose la apuesta estadounidense por la fórmula del arbitraje obligatorio y, por añadidura, por su intención de que el tribunal fuese permanente y con sede en Washington.

Probablemente las expectativas de Blaine pecaron de exceso respecto a las posibilidades de la Conferencia, pero su frustración no invalidó el potencial del panamericanismo conforme a lo que acabaría siendo: una de las dinamos de la política exterior norteamericana. Hablamos de un instrumento perfectamente articulado con las distintas directrices que guiaron el actuar estadounidense fuera de sus fronteras y, en particular, al sur de las mismas, entrando en consonancia con discursos previos como la Doctrina Monroe o la Doctrina del Destino Manifiesto que - además de evidenciar

${ }^{6}$ La I Conferencia Internacional Americana, celebrada en Washington del 2 de octubre de 1889 al 19 de abril de 1890 .

7 Andrés García, 2017, 287-288. 
la temprana oposición estadounidense a las intervenciones europeas en América $^{8}$ - también revelaría el complejo de superioridad y el providencialismo característicos del expansionismo norteamericano. Fue así como, en una línea de continuidad, la posterior Diplomacia del Big Stick, implementada bajo el mandato de Theodore Roosevelt, o la del Dólar - también apuntada por Roosevelt pero impulsada, sobre todo, durante el gobierno de William Taft - encontraron en el discurso panamericanista un engranaje en el que acoplar - desde una percepción supremacista, como la que albergaba la clase política norteamericana respecto a sus vecinosla influencia política, el expansionismo económico y la amenaza militar, cuando no la intervención.

La respuesta latinoamericana, doctrinalmente hablando, tendría expresiones diversas. En una época ideológicamente ardua, junto al hispanoamericanismo convivirían otros movimientos de singular importancia como el latinoamericanismo ${ }^{9}$, si bien no centraremos nuestra atención en ellos tanto por motivos de espacio como la limitada importancia que éstos tendrían en España. Lo cierto es que el hispanoamericanismo, en sus distintas versiones, signó la política y la cultura españolas de manera inapelable lo que, unido al aludido cambio de perspectiva que se produciría en la América Hispana tras 1898, produjo la paradoja de una reivindicación del legado español a un lado y otro del Atlántico, aun por motivos bien diferenciados.

En el caso español, la reivindicación de una identidad cultural colectiva se impondría por razones varias, no siendo desdeñable su uso para

${ }^{8}$ Las potencias europeas - y, en particular, Gran Bretaña y Francia - intensificaron su presencia en el continente tras las independencias, justificando sus intervenciones en la supuesta protección de sus súbditos o en la siempre socorrida excusa de garantizar el pago de las deudas contraídas por los gobiernos latinoamericanos con sus bancos e inversores. En el caso británico esto vino a complementarse con el apresurado interés de los nuevos ejecutivos por lograr el reconocimiento de Londres; reconocimiento acompañado, con frecuencia, de tratados comerciales que darían a Gran Bretaña una posición privilegiada dentro del nuevo contexto. En todo caso, cuando la diplomacia no dio los frutos esperados, siempre quedaría la intervención militar, siendo que, ya en la primera mitad del XIX, México, Nueva Granada y el Río de la Plata sufrirían bloqueos navales por parte de franceses y británicos.

${ }^{9}$ La bibliografía sobre el latinoamericanismo, sus antecedentes y representantes han disfrutado de un impulso interesante desde los estudios de Leopoldo Zea. Algunas de las aportaciones más sugerentes de los últimos años son, desde perspectivas diferentes, las de Miguel Barrios en relación a Manuel Ugarte (2004) o la de Alexandra Pita y su estudio sobre la Unión Latinoamericana y el boletín Renovación (2009). 
paliar el descalabro de su ya dañada imagen internacional. Cierto es que, independientemente de las variables existentes dentro del hispanoamericanismo, se produjo una anteposición de los valores culturales hispanos sobre el resto de intereses, lo que podría traducirse como la primacía de una convicción - la existencia de una comunidad de base histórica, linguiística y cultural - por encima de cualquier otro rédito. Sin embargo, la cuestión sería hasta qué punto la España de comienzos del XX estaba preparada para otro tipo de planteamiento. $\mathrm{O}$, dicho de otro modo, hasta dónde llegaba la capacidad de la vieja metrópoli para impulsar y consolidar un proyecto político y/o económico a la altura, en sus beneficios, de la comunidad cuyo liderazgo pretendía arrogarse ${ }^{10}$.

En lo concerniente a las repúblicas hispanoamericanas, la reivindicación de la herencia española se convertiría en una de las principales líneas argumentales a oponer al expansionismo estadounidense. España, expulsada definitivamente del continente, había dejado de ser una amenaza para sus antiguas colonias, lo que facilitaría la asunción de su legado como elemento clave de las identidades propias y fundamento integrador de una posible identidad colectiva o, cuando menos, de su planteamiento ${ }^{11}$. Tales mimbres alimentarían el alegato de aquellos sectores opuestos a la adopción, sin reservas, del modelo norteamericano como política de Estado. Una medida asumida por no pocos gobiernos latinoamericanos como garantía de progreso, pero cuyas consecuencias apuntaban a ser imprevisibles no sólo en lo político y lo económico, sino también en el ámbito sociocultural ${ }^{12}$.

10 Sepúlveda, 1994, 18-20; Andrés García, 2014, 607.

11 Esto no quita para que los debates en torno al hispanoamericanismo -o, más bien, en torno al legado hispano- no estuviesen presentes en la vida intelectual de los distintos países. México, por ejemplo, oscilaría entre una cierta aceptación presente durante el porfiriato y el posterior rechazo vigente con la consolidación estatal del México post-revolucionario, en el que encontrarían mejor acomodo otros movimientos como el latinoamericanismo, el indigenismo o el indoamericanismo. Colombia, al cambio, vivió una clara compenetración de las ideas hispanistas con la cultura y la política patrias, encontrando en el legado español fundamentos de cohesión social y cultural - como la religión y el idioma - que consolidarían el discurso político de los sectores conservadores hasta bien entrado el siglo Xx. Para una mayor información sobre los debates y evolución del hispanismo/hispanoamericanismo en ambos países merece la pena la lectura de Granados, 2010 y Gracia, 2011.

12 No parece exagerado si observamos lo acontecido en Filipinas, donde la administración norteamericana - una vez reprimida la resistencia local- logró, en apenas unas décadas, reducir a la mínima expresión el uso del español e impulsar su sustitución por el in- 
Con tales elementos no resulta extraño que, en tierras americanas, el ensalzamiento de la tradición hispánica cobrase, con frecuencia, un marcado acento antiimperialista. Un acento que bien podría vincularse a la ya asentada tendencia del hispanoamericanismo por hacer bandera del antiyanquismo y que, a su vez, explicaría el seguimiento que la prensa española haría de aquellos acontecimientos y personajes que, como Sandino, pusieron en evidencia el intervencionismo estadounidense y sus abusos.

\section{La cuestión de Nicaragua}

No puede decirse que el interés de Washington por Nicaragua fuese repentino. Ya la aparición del oro californiano en 1848 hizo que la importancia geopolítica de la región creciese exponencialmente. Firmado ese mismo año el Tratado de Guadalupe-Hidalgo - y ampliadas las fronteras hasta el Pacífico a costa de México - el control del istmo se convertiría en un objetivo fundamental para los norteamericanos, entrando en competencia con una Gran Bretaña cómodamente posicionada en el continente tras el triunfo independentista.

Fue en el marco de esta disputa que, apenas un año después, el ejecutivo estadounidense inició negociaciones con las autoridades nicas con la mira puesta en la construcción de un canal interoceánico. La maniobra no pasó desapercibida al gobierno de Londres, sumamente interesado en el proyecto pero no en que quedase en manos rivales, de ahí que, tras diversas tensiones, se lograse cierta conciliación con la firma, el 19 de abril de 1850, del Tratado Clayton-Bulwer, que restringiría las ambiciones territoriales de ambas potencias y conformaría a sus respectivas clases políticas, al menos temporalmente, respecto a cuál de las dos iba a ejercer el control exclusivo sobre el futuro canal ${ }^{13}$.

glés. Así se entiende el esfuerzo de intelectuales como el dominicano Eugenio Deschamps o el puertorriqueño José de Diego por crear un importante número de centros educativos con un doble objetivo: educar y concienciar de la propia identidad. Lo mismo en cuanto al mexicano Julián Carrillo quien, siendo director de la Escuela Nacional de Música y Arte Teatral de México - y asustado de que los estudiantes de su país se ufanasen de estudiar en francés e inglés - llegaría a proponer la creación de una Confederación proidiomática que promoviese el uso de de libros en castellano y la unificación de las normas de traducción, a fin de que en las escuelas primarias superiores de los países hispanohablantes no se utilizaran obras en lenguas extranjeras. Sepúlveda, 2005, 215.

13 Selser, 2010b, 12. 
La provisionalidad del tratado quedaría patente cuatro años después con el bombardeo y destrucción del puerto de Greytown ${ }^{14}$ por el buque de guerra norteamericano Cyane. Greytown controlaba la desembocadura del río San Juan, punto clave para todo aquel que quisiera emprender la proyección de un canal por Nicaragua. Ocupado por los británicos el 1 de enero de 1848 con las bendiciones del rey misquito, George Augustus Frederic II, el puerto nunca dejó de ser un punto de fricción entre ambas potencias, convirtiéndose en la causa de su primer enfrentamiento armado. Lo cierto es que, pese a lo firmado, las escaramuzas entre ingleses y estadounidenses nunca dejaron de producirse, al punto que - tras el incidente del Cyane - hubo que consensuar nuevamente las posiciones en pos de evitar un choque a gran escala.

Los rifirrafes entre Londres y Washington ilustrarían la importancia geoestratégica centroamericana para el comercio internacional, al igual que el papel secundario otorgado por ambas potencias a las soberanías de la zona. Tal desdén podría ejemplificarse en la pertinente utilización del providencial reino de Mosquitia por parte de los británicos ${ }^{15}$; o en las muy oportunas incursiones de William Walker en la región, que pondrían sobre el tapete los muchos intereses particulares yanquis implicados en el asunto. Lo que resulta indudable es que las injerencias de unos y otros alimentaron la inestabilidad de la zona, supeditando a los ejecutivos regionales a un grado tal que, con frecuencia, hubieron de relegar las conveniencias nacionales en virtud de las presiones externas.

A comienzos del xx la disputa por la supremacía parecía abocada en favor de los norteamericanos. Una supremacía agudizada, además, por la paulatina implantación de empresas estadounidenses y la captación e integración, dentro de sus cuadros, de miembros de las elites políticas centroamericanas. Así se entiende el incordio que supondría para los planes de Washington un presidente como el nicaragüense José Santos Zelaya, impulsor de proyectos de carácter interregional opuestos al intervencionismo

${ }^{14}$ El antiguo San Juan de la costa caribeña nicaragüense. El cambio de nombre se hizo por iniciativa del rey misquito, George Augustus Frederic II, en honor del gobernador de Jamaica, sir Charles Grey.

15 Por ejemplo, cuando el rey misquito Robert Charles Frederick, en 1839, cedió a súbditos ingleses residentes en Jamaica una extensión de terreno «libre y exento de contribuciones, impuestos y gravámenes de toda clase» que cubría buena parte de las actuales Nicaragua, Costa Rica y Panamá. Con ello, los británicos se otorgarían una legitimidad para intervenir en el área totalmente ajena a la voluntad de los gobiernos centroamericanos. Selser, 2010a, 279. 
foráneo ${ }^{16}$ y que, tras no pocos roces con el Departamento de Estado norteamericano, acabaría siendo víctima de sus manejos y partiendo al exi$\operatorname{lio}^{17}$.

La expatriación de Zelaya y la derrota de su sucesor, José Madriz Rodríguez, puso la política nicaragüense en manos de los Estados Unidos. La heterogeneidad de la que había hecho gala hasta entonces la oposición - con facciones enfrentadas como la del liberal Juan José Estrada y la del conservador Emiliano Chamorro - favoreció, además, el actuar del sibilino Thomas G. Dawson, agente norteamericano que, aprovechando las disensiones internas, logró que los rebeldes aceptasen las condiciones pergeñadas por su gobierno, incluyendo la solicitud de un empréstito que, conferido por la Brown Bross \& Company, pondría el control financiero del país en manos de dicha compañía ${ }^{18}$.

El efecto de tales cesiones quedaría de manifiesto en todos los ámbitos. Sobra decir que la presidencia del país acabaría recayendo en Adolfo Díaz quien, en su condición de antiguo empleado de la compañía minera La Luz y Los Ángeles Mining Co., desempeñaría ejemplarmente el rol que el capital norteamericano dispensaba a las elites locales dentro de sus organigramas ${ }^{19}$. En cuanto a la vida política, el conservadurismo inicia-

16 Entre otros el Pacto de Amapala, en 1895, con el que se pretendió la creación de una nueva federación centroamericana con Honduras, Nicaragua y El Salvador como punto de partida. Lo que serían los efímeros Estados Unidos de Centroamérica, instaurados el 27 de agosto de 1898, apenas perdurarían unos meses, ya que en noviembre de ese mismo año un golpe de Estado en El Salvador expulsaría a los liberales del poder y el nuevo gobierno, encabezado por Tomás Regalado, oficializaría su salida de la federación y el fin del proyecto.

17 Andrés García, 2017, 291-293.

${ }^{18}$ La dependencia bancaria del país respecto a esta compañía llevaría a Nicaragua a ser referida, en determinados círculos, como «la república de los hermanos Brown». Quijano, 1987, 202-203.

19 Prueba de ello sería su actuación en la solicitud de un empréstito a la banca de Wall Street por valor de 15 millones de dólares. Las negociaciones entre el secretario de Estado, Philander Chase Knox, y el encargado de negocios nicaragüense, Salvador Castrillo, desembocaron en un pliego de condiciones leonino para los intereses centroamericanos. Para mayor escarnio, el acuerdo ni siquiera fue traducido del inglés para su discusión en el Congreso nicaragüense, habiendo órdenes taxativas del plenipotenciario Weitzel de que el texto fuese aprobado sin la menor variación. De resultas de todo ello seis diputados y dos secretarios de Gobierno se negaron a suscribir el escrito, no pudiendo impedir, en todo caso, su aprobación por el resto de la Cámara. Sorprendentemente, serían las renuencias legales del Senado estadounidense las que impidieron que saliese adelante, rechazándolo hasta tres veces pese a las presiones del presidente Taft. Selser, 1984, 41. 
ría un periodo de predominio que, sin embargo, no evitaría las luchas internas por el poder, quedando limitadas las opciones liberales $-\mathrm{a}$ falta de postulantes propios - a secundar a aquellos candidatos conservadores con los que guardasen menos disparidad.

Washington quedaría durante estos años como árbitro de la situación, llegando a ser solicitada su presencia militar hasta en dos ocasiones: la primera, poniendo fin a la Revolución Libero-Conservadora de 1912; la segunda, durante la Guerra Constitucionalista de 1926. En ambos casos el gran beneficiario sería Díaz: en 1912, garantizando la intervención su permanencia en la poltrona presidencial; en 1926, haciendo que, lo que comenzó como una disputa por el poder entre los conservadores Carlos Solorzano y Emiliano Chamorro, terminase con él de nuevo en la presidencia $^{20}$. Entre medias, la dependencia respecto a Washington no haría sino apuntalarse, trasluciéndose en acuerdos como el Tratado Bryan-Chamorro $^{21} \mathrm{o}$ en la presencia permanente en el país, entre 1912 y 1925, de un pequeño contingente de marines de apenas 400 hombres que, pese a su escaso número, simbolizaría sin ambages la supeditación del país al gigante yanqui.

Es al trasluz de lo expuesto que se entiende la relevancia que cobraría Sandino tras su negativa a acatar el Pacto del Espino $\mathrm{Negro}^{22}$, un acuerdo forzado por los Estados Unidos que, de entrada, obligaría a dejar a Díaz como presidente hasta finalizar su mandato, previéndose la celebración de elecciones para 1928.

${ }^{20}$ La disputa entre Solorzano y Chamorro devino por la inclusión en el gabinete del primero de un vicepresidente liberal, Juan Bautista Sacasa. El levantamiento de Chamorro logró la dimisión de Solorzano pero no el respaldo de Washington, que impuso a Díaz como mandatario por segunda vez, siendo la negativa de los liberales a quedar fuera del gobierno la que abriría las puertas al nuevo conflicto.

21 Suscrito en 1914, fue el complemento perfecto al firmado con Panamá, en 1903, a cuenta del canal. Si con el Hay-Bunau Varilla los panameños accedieron a todas las peticiones estadounidenses a un precio ínfimo - apenas diez millones de dólares - con el Bryan-Chamorro los norteamericanos se aseguraron, por tan solo tres, la cesión a perpetuidad de los derechos de construcción de otro a través de Nicaragua, además de los derechos - por 99 años, renovables por otros tantos - para construir una base militar en el golfo de Fonseca y el arriendo de las islas del Maíz para su protección. De esta manera, los Estados Unidos no sólo se asegurarían el control sobre la zona, sino que también despejaría toda posibilidad de competencia por parte de otras potencias.

${ }^{22}$ Rubricado en Tipitapa el 7 de mayo de 1927, no fue firmado por Sacasa, quien prefirió partir al exilio. No ocurriría igual con su jefe militar, José María Moncada, quien aceptó las condiciones convenidas en el texto. 
Hasta entonces, cualquier observador externo tenía asumido que el devenir político y económico centroamericano - así como el caribeño- se decidía, en última instancia, en la Casa Blanca, con funestas consecuencias para quien se opusiese a sus designios ${ }^{23}$. Empero, que seis meses después de la firma de Tipitapa los marines se viesen incapaces de derrotar a ese oscuro comandante guerrillero no pudo, por menos, que despertar la curiosidad y admiración generales. Un reflejo que, a la par, engrosaría las dudas de la opinión pública internacional sobre el papel norteamericano en el conflicto, la probidad del gobierno de Díaz y, ante todo, la personalidad de quien, con tan escasos medios, lograba hacer frente, contra pronóstico, a la mayor potencia militar del continente.

\section{Sandino y la prensa española}

Es importante señalar el desconocimiento que la prensa española tenía de Sandino antes de su negativa a deponer las armas. Desconocimiento extensible al resto de medios internacionales y comprensible en cuanto que no fue hasta su participación en la Guerra Constitucionalista que su nombre comenzó a sonar. Fue con la publicación de los primeros artículos sobre su persona que se dieron a conocer sus simpatías liberales, su admiración por Benjamín Zeledón ${ }^{24}$ y las suspicacias de los líderes rebeldes,

${ }^{23}$ Basta revisar las diversas intervenciones militares estadounidenses para constatarlo. En Cuba, actuaron hasta en cuatro ocasiones: 1898-1902; 1906-1909, 1912 y $1917-$ 1922; Guatemala sufriría otra en 1910; Haití, entre 1915 y 1934; Honduras, en 1903, 1907, 1911, 1912, 1924 y 1925; México, en 1914 y 1917; Puerto Rico, en 1898; y la República Dominicana en 1903, 1904, 1905, 1912 y 1916-1924. Si a ello sumamos que en la propia Nicaragua ya habían intervenido en 1909-1910 y el periodo 1912-1925 podemos hacernos una idea de cuán intimidante resultaba la política norteamericana en la región. Martí, 2004, 31.

${ }^{24}$ Político, diplomático y militar nicaragüense que, tras ejercer diversas responsabilidades durante el gobierno de José Santos Zelaya, se destacó en la conocida como Revolución Libero-Conservadora de 1912 contra Adolfo Díaz y Emiliano Chamorro. Díaz, al igual que estaba aconteciendo en esos momentos, también echó mano del apoyo militar estadounidense, siendo decisivo en la derrota y muerte de Zeledón en la batalla de Coyotepe. Sandino llegaría a ver el cadáver del líder liberal en Catarina, ciudad vecina a la suya, Niquinohomo, manifestando su admiración por el finado al haberle dado «la clave de nuestra situación nacional frente al filibusterismo norteamericano; por esa razón, la guerra en que hemos estado empeñados, la consideramos una continuación de aquella». Sandino, 2009, 18. 
Sacasa y Moncada, ante un Sandino remiso a plegarse a sus componendas en las negociaciones con los norteamericanos ${ }^{25}$.

Hasta Tipitapa el conflicto nicaragüense había tenido un seguimiento dispar en los medios peninsulares, siendo evidente cierto interés pero sin que éste se diferenciase del ya observado en otras injerencias norteamericanas. Una revisión a las noticias publicadas en esos meses muestra la insistencia de las distintas cabeceras por resaltar la presencia de tropas estadounidenses en el país, dando tratamiento protagónico a quienes, sobre el papel, habían acudido requeridos por el gobierno vigente. No hubo distinción ideológica a la hora de referir tal detalle, siendo visible en diarios de talante progresista como $\mathrm{El} \mathrm{Sol}{ }^{26}$ y de corte conservador, como $\mathrm{El} \mathrm{Im}$ parcial $^{27}$; en periódicos con un creciente tirón popular, como $\mathrm{La} \mathrm{Voz}^{28}$ y aquellos de público más restringido, como el monárquico La Época que, tomando a Walker y su recuerdo como excusa, esbozaría en por-

25 El desembarco de los marines en Puerto Cabezas en diciembre de 1926 para «proteger las vidas e intereses de los ciudadanos norteamericanos» residentes en la ciudad hizo que Bautista y Sacasa cesasen la lucha y se plegasen a las exigencias de los recién llegados con vistas a iniciar conversaciones. La propuesta de Sandino de continuar la resistencia en Las Segovias fue rechazada por ambos, negándosele las armas para tal propósito. Por suerte para Sandino, las prisas constitucionalistas por desalojar Puerto Cabezas - tal y como habían exigido los mandos norteamericanos - hizo que parte de sus pertrechos quedasen atrás. Pertrechos que, arrojados al agua por los marines, serían recuperados por los hombres de Sandino con ayuda de algunos nativos misquitos, partiendo a continuación a Las Segovias. Sandino, 2009, 40-41.

26 Con titulares llamativos como «El imperialismo norteamericano. Los soldados de Estados Unidos van a atacar a los liberales de Nicaragua»; en El Sol, 19 de julio de 1927, p. 5.

27 Como ejemplo, la noticia sobre la batalla de Ocotal, acontecida el 16 de julio, y en la que la guerrilla fue atacada por fusileros norteamericanos y fuerzas gubernamentales. Una noticia que, en un ejercicio de lógica política, plantearía las acciones futuras contra los sandinistas conforme al accionar de las autoridades estadounidenses, dejando en un segundo plano las declaraciones del ejecutivo de Managua. «La rebelión en Nicaragua. Ataque a las tropas del general Sandino»; en El Imparcial, 28 de julio de 1927, p. 1.

${ }^{28}$ Que, prácticamente desde el inicio, se haría eco de las denuncias de los liberales nicaragüenses en cuanto a los excesos del gabinete Coolidge y de los marines: «El informe del coronel norteamericano Gulick dice que, además de los 300 muertos habidos en el bombardeo, muchos heridos que se refugiaron en los bosques han muerto, y sus cadáveres van apareciendo [...] El doctor Baca, representante de los liberales de Nicaragua en Norteamérica $[. .$.$] Dice que los norteamericanos han matado a los patriotas que se negaron a$ arrodillarse y aceptar la paz impuesta por Stimson, enviado particular y representante personal de Coolidge». «Nicaragua - Los liberales, perseguidos»; en $\mathrm{La}$ Voz, 22 de julio de 1927 , p. 5 . 
tada cómo, desde la época del filibustero, la historia nicaragüense se había visto trufada de intromisiones yanquis, siendo la de ese momento el último eslabón de una larga cadena:

«... Nicaragua estaba y está, sin duda, destinada a sufrir las invasiones, más o menos veladas, de los Estados Unidos [...] en los momentos actuales es tan patente y decisiva la intromisión de la Unión en los asuntos interiores de Nicaragua, que los fusileros norteamericanos luchan, confundidos con las tropas conservadoras de Díaz, contra los restos de las huestes liberales acaudilladas por Sandino.

Tal vez la vida de los pueblos, tan semejante a la de los hombres, se desenvuelve bajo las normas inexorables de un destino adverso; sobre el hermoso suelo de Nicaragua flota y flotará siempre el fantasma de Walker, y sobre todos sus directores y presidentes, sea cualquiera su orientación política, y según frase acertada de Rubén Darío, pesará, por una eternidad, la sombra gigantesca de los Estados Unidos. ${ }^{29}$

Los meses siguientes las noticias discurrirían entre las protestas de la prensa internacional por los desmanes cometidos en el país centroamericano. Incluso los diarios británicos harían notar la acritud con que era contemplada la intervención en los círculos políticos londinenses ${ }^{30}$. Autores hubo, como Camilo Barcia Trelles, que resaltarían el decisivo rol de Wall Street dentro de la escena política centroamericana, ya fuera controlando sus economías y gobiernos a través de empréstitos e inversiones, ya fuese forzando la agresión militar cuando dicho control resultaba inefectivo:

«Pero en ocasiones el imperialismo del dólar no basta: puede tropezar con resistencias, entorpecerse su acción, porque a la misma se oponen quienes, poseyendo un alto sentido del porvenir de Centroamérica, trabajan por su manumisión económica. Entonces se apela al empleo de fuerzas de desembarco. A pretexto de defender determinados intereses, la intervención se produce; se apoya decididamente al candidato compaginador, y una vez restaurados en el Poder los dictadores al dictado de la Wall Street, la actividad sojuzgadora prosigue. Tal ha sido el desenlace previsto en la lucha mantenida entre Díaz y el doctor Sacasa:

29 Joaquín Gallardo Rúa, «Nicaragua y sus filibusteros»; en La Época, 28 de julio de 1927, p. 1.

30 «La intervención norteamericana en Nicaragua - Inglaterra protesta contra la intervención»; en $L a$ Voz, 23 de julio de 1927, p. 5. 
el epílogo era fácilmente anticipable. En Nicaragua no cristalizará movimiento político alguno que no sea grato a los prestamistas norteamericanos. Pueden decirnos algo sobre este particular los efectivos militares de Sandino, ametrallados por las tropas de desembarco yanquis.» ${ }^{31}$

Un análisis como el de Barcia descartaría, de antemano, la validez de unas elecciones como las concertadas en el Pacto del Espino Negro. Aparte, Sandino recalcaría desde un principio el carácter patriótico de su rebeldía, descartando negociar con el gobierno el cese de las hostilidades mientras fuerzas extranjeras permaneciesen en el país. Dicha decisión le granjearía, todavía más, el aprecio y la adhesión del público español y latinoamericano, sobre todo conforme fueron llegando los primeros éxitos, como la toma de Ciudad Antigua a fines de ese mismo año.

La celebración, a comienzos de 1928, de la VI Conferencia Internacional Americana en La Habana abrió un nuevo escenario para la controversia. Si los prolegómenos ya vinieron cargados de rumores sobre la muerte de Sandino y los planes de Washington para acabar con él a cualquier precio ${ }^{32}$, la reunión no desmerecería en cuanto a polémica, desencuentros y provocaciones. Una de las más comentadas fue la ovación generalizada dispensada a las banderas de México y Nicaragua al ser trasladadas, con las del resto de países miembros, al salón de sesiones. Otra, no menor, sería la propuesta mexicana para que la dirección general de la Oficina de la Unión Panamericana dejase de ser monopolio de los Estados Unidos y pasase a ser rotativa, lo que sería acerbamente criticado por el portavoz norteamericano, Charles Evans Hughes, con el argumento de que dicho cargo debía ser ejercido permanentemente por «una personalidad de verdadera influencia diplomática ${ }^{33}$.

31 Camilo Barcia Trelles, «Nicaragua, protectorado yanqui - Servidumbre contractual»; en La Libertad, 4 de agosto de 1927, p. 1.

32 «El ministro de Marina, Curtis Wilfur, ha declarado que habrá más tropas dispuestas para embarcar en cualquier instante. El nombramiento del general Logan Feland para dirigir la campaña indica que se van a emprender operaciones a gran escala. Esta opinión se confirma en los círculos políticos, atribuyéndose a Coolidge el propósito de acabar con Sandino, cueste lo que cueste. El ministro del Exterior ha declarado, además, que Norteamérica está dispuesta a restablecer a todo trance el orden en Nicaragua». «Imperialismo norteamericano - Se prepara en Nicaragua una enérgica acción militar»; en El Sol, 5 de enero de 1928 , p. 7.

33 «En La Habana - La Conferencia panamericana continua sus trabajos»; en Heraldo de Madrid, 25 de enero de 1928, p. 1. 
A pesar de las aparentes dificultades pasadas por la delegación norteamericana - las discusiones respecto al «derecho de intervención» fueron particularmente espinosas - la desunión de los representantes latinoamericanos hizo que, al menos desde una perspectiva institucional, Washington superase la reunión sin grandes apuros y, sobre todo, sin compromisos inmediatos ${ }^{34}$. No obstante, a lo largo de la conferencia la figura de Sandino iría creciendo de cara al gran público, sobre todo por la cada vez más patente incapacidad de las fuerzas norteamericanas para derrotarlo. El envío de refuerzos desde los Estados Unidos, las incipientes críticas internas a la administración Coolidge y los sucesivos fracasos sobre el terreno vinieron a enaltecer, aún más, los mensajes de Sandino a sus partidarios y simpatizantes. Mensajes que, por otra parte, transmitirían una imagen épica del guerrillero, exaltando su figura con un aura de patriotismo y sacrificio que acabaría calando con fuerza en el imaginario hispanohablante. La lectura de un reporte publicado por La Época en las previas de la Conferencia de La Habana revela adecuadamente lo dicho. Haciendo referencia a una carta enviada por Sandino a un amigo $-\mathrm{y}$ filtrada por Pedro Cepeda, su representante en México según la prensa - las palabras atribuidas al guerrillero no podían, por menos, que investirlo con los ropajes de héroe:

«Lucharé mientras el corazón no deje de palpitar [...] Nicaragua no será de los imperialistas. Tengo cinco toneladas de dinamita en mi arsenal, que haré estallar con mis propias manos. Los que oigan el estruendo sabrán que Sandino ha muerto; pero las manos de traidores e invasores no profanarán sus restos. Tan solo Dios Todopoderoso y los verdaderos patriotas juzgarán..$^{35}$

Los intentos norteamericanos por aislar a Sandino tendrían un éxito muy relativo. Su área de actuación era limítrofe con la frontera hondureña, lo que le garantizaba una salida de emergencia en caso de peligro. A ello habría que sumarle la ofuscación de sus enemigos a la hora de contrarrestar su creciente popularidad. Cada carta de Sandino dejaría en evidencia el fracaso de tales propósitos, incrementando todavía más su fama

34 Andrés García, 2017, 295-304.

35 «Los Estados Unidos y Nicaragua - Una carta de Sandino»; en La Época, 9 de enero de 1928 , p. 1. Hay que señalar que otros periódicos, como El Sol, ya habían informado sobre la misiva el día anterior. 
el bloqueo al que se le pretendía someter. Un editorial de El Sol del 20 de enero ilustra lo dicho de manera fehaciente, resaltando las dificultades interpuestas al rebelde para evitar que sus palabras llegasen al gran público $^{36}$, antes de dar paso a una nueva carta en la que, de nuevo, su figura se investiría con la vitola de patriota irreductible frente a la intromisión extranjera y el consentimiento de sus gregarios:

«Desconocemos todo acto que emana del traidor Adolfo Díaz. Es nuestro propósito arrojar del país, en la forma que hubiere lugar sin lesionar los intereses de la nación, a los piratas que invaden nuestra patria $[\ldots]$

Permanecer en armas, jurando ante la patria y la historia no vendernos ni rendirnos hasta no arrojar de nuestro suelo a los invasores.

No permitir que poderes extraños sean los guardianes de las armas que sirven para defender el decoro de la patria, y, en esa virtud, no permitir tan humillante propuesta, pues no necesitamos que los invasores vengan a darnos garantías a los hijos legítimos del país; estas garantías sólo pueden ser efectivas desocupando los piratas de nuestro territorio.» ${ }^{37}$

La carta de Sandino vino a publicarse pocos días después de la inauguración de la cita habanera y de un discurso, el del presidente Coolidge, muy criticado desde las tribunas internacionales por pasar de puntillas sobre los asuntos que, verdaderamente, enturbiaban las relaciones interamericanas como, por ejemplo, el derecho de intervención que el monroísmo otorgaba a los Estados Unidos o, de resultas de éste, la cuestión de Nicaragua $^{38}$. De ahí se deducen las bajas expectativas periodísticas a una posi-

36 «La Prensa imperialista de los Estados Unidos ha tratado de presentar a las fuerzas del general Sandino como una partida de bandoleros, y el enérgico bloqueo ejercido por las autoridades norteamericanas de Nicaragua impide a Sandino comunicarse libremente con el resto del mundo y hacer constar sus propósitos y organización». «La defensa de Nicaragua»; en El Sol, 20 de enero de 1928, p. 1.

37 La carta vino de la mano de Fabyan Turcios, director de la revista guatemalteca Ariel y colaborador de Sandino hasta su ruptura de relaciones en enero de 1929. Funes, 2010.

38 Un titular de El Sol revelaría tal desconfianza ya en los comentarios al discurso de Coolidge, subtitulándolo «La delegación norteamericana quiere establecer el derecho de protectorado de los Estados Unidos "en dirección al sur hasta el Cabo de Hornos"». En «La Conferencia Panamericana - Se comenta desfavorablemente el discurso de Coolidge»; en El Sol, 21 de enero de 1928, p. 7. 
ble rectificación por parte de Washington; o las duras críticas vertidas por reputados cronistas, como Eduardo Gómez de Baquero «Andrenio», quien desmontaría con sorprendente aspereza las buenas intenciones que pudieran desprenderse de la alocución de Coolidge:

«Los dos grandes principios son, según Mr. Coolidge, la democracia y la paz $[\ldots]$ hay que reconocer que, en teoría, las declaraciones de Mr. Coolidge son excelentes.

Lo malo es la práctica. El mismo día que se inauguró la Conferencia de La Habana desembarcaba en Corinto (Nicaragua) otro destacamento de Infantería de Marina norteamericana con abundante tren de municiones y aviones de bombardeo [,,,]

Algo tiene que haber en la psicología de la gran República yanqui, medio puritana medio fenicia [...] que explique la contradicción entre la doctrina y la conducta. La clave está probablemente en la creencia de la inferioridad de los pueblos hispanoamericanos en relación a su robusto vecino del Norte.

La repugnancia y el desprecio hacia las razas de color que hace perseguir las huellas del antepasado negro, en personas de sangre mezclada, que ya no son de color y ofrecen el tipo caucásico, es un antecedente del desdén del yanqui hacia el criollo español de las Repúblicas del Centro y del Sur, sentimiento oculto e inconfesable [...] que ya no se apoya sólo en la prevención contra el mestizaje más o menos extendido en aquellos pueblos, sino en su relativa - a veces grande, a veces muy pequeña - inferioridad política e industrial. El yanqui mira a los pueblos hispanoamericanos que tiene más cerca como menores necesitados de tutela o como sociedades donde coloca sus capitales y desea tener, en consecuencia, cierta facultad de vigilancia e intervención.» ${ }^{39}$

Fue en este contexto que se iría fraguando una imagen distintiva de Sandino en los medios españoles. Una imagen que partiría de su condición rebelde, de su resistencia frente a la presencia estadounidense en su país, pero que, con el tiempo, iría cobrando matices específicos según el signo político de la publicación que la abordase. Una revisión de los artículos editados en la península durante esos meses confirma el primer extremo, con diarios de ideología dispar que, sin embargo, coincidirían en recalcar la índole partisana del nicaragüense y en su equiparación con fi-

39 Eduardo Gómez de Baquero, «Del panorama mundial - El discurso de Mr. Coolidge ante la Conferencia Panamericana»; en El Sol, 21 de enero de 1928, p. 1. 
guras históricas españolas que la tradición había encumbrado como grandes guerrilleros. Es así como podemos encontrar a un Augusto Barcia que, desde las páginas de La Libertad, calificaría a Sandino como «el Viriato nicaragüiense» ${ }^{40}$; o la silueta editada por El Imparcial en la que compararía a éste con los héroes de la Guerra de la Independencia Española ${ }^{41}$; o el panegírico que le dedicaría el socialista Benito Artigas Arpón en La Voz y que, en línea con los anteriores, asimilaría al centroamericano con El Empecinado hasta vincularlo, en retrospectiva, con los cántabros y su lucha contra los romanos:

«No le ha faltado a Sandino, el «Empecinado» de Nicaragua, el apóstrofe que esgrimen los pueblos invasores contra los núcleos reasumidores de la defensa de la independencia y contra sus capitanes. Al general Sandino se le ha llamado bandolero y jefe de bandoleros por figuras representativas del pueblo contra cuya invasión se alzó el general de Nicaragua. Bandoleros fueron Viriato y sus huestes, así como los cántabros indómitos, para los romanos. Bandoleros, nuestros guerrilleros, para los ejércitos napoleónicos. Y bandolero tenía que ser ese ejemplo vivo de abnegación, de amor a la independencia, que se llama César Augusto Sandino [sic]. El dicterio, de procedencia norteamericana, es el basamento sobre el cual se alza en Nicaragua la única columna de la libertad que queda enhiesta.» ${ }^{42}$

El hispanoamericanismo no dejaría pasar la ocasión para vindicar a Sandino como representante de la Raza, distintivo clásico del movimiento que - encarnado en su figura - haría transcender la lucha por la independencia de su país a la categoría de causa continental. Con ello, la resistencia sandinista pasaría también a convertirse en santo y seña del antiimperialismo latinoamericano, lo que se traduciría en multitud de alegatos en los que el nicaragüense aparecería reflejado — frente al entreguismo de las

40 Hablando de un manifiesto de la juventud universitaria bonaerense en apoyo «... a Sandino, al Viriato nicaragüense, carne y sangre de aquel admirable caballero, valiente, señor e indómito, que pintara el inmortal Rubén». Augusto Barcia, «La Conferencia de La Habana - Los primeros frutos»; en La Libertad, 25 de enero de 1928, p. 1.

41 «Al igual que nuestros héroes de la Independencia, Sandino ha recorrido el territorio de su país, realizando actos de tal audacia y de tan increíble valor personal, que puede decirse que es hoy la figura más entusiásticamente admirada de América». En «La Revolución en Nicaragua - Silueta del general Sandino»; en El Imparcial, 27 de enero de 1928, p. 8.

42 Benito Artigas Arpón, «En Centroamérica - Cesar Augusto Sandino o la libertad»; en $\mathrm{La}$ Voz, 1 de febrero de 1928, p. 4. 
clases dirigentes - como símbolo de la disconformidad de sus pueblos y defensor de la dignidad colectiva ${ }^{43}$.

La revista La Rábida, órgano de la Real Sociedad Colombina Onubense, sería, sorprendentemente, un buen escaparate a este respecto. Y hablamos en término de sorpresa porque, siendo ésta una publicación más bien representativa del hispanoamericanismo conservador, en sus páginas tuvieron cabida artículos, opiniones y homenajes a Sandino de personalidades bien significadas por su izquierdismo, como Manuel Ugarte o César Falcón. En el caso de Ugarte, refrendando el orgullo colectivo por su lucha contra, en sus palabras, los grandes enemigos de los pueblos del Sur, es decir, «la plutocracia norteamericana y [...] las oligarquías y los tiranos que son servidores más o menos visibles del imperialismo»44:

«No admitamos, pues, diferencias entre liberales y conservadores y hagamos bloque contra los derrotistas, contra los Presidentes ungidos por la Casa Blanca, contra todas las encarnaciones que toma en nuestras repúblicas el mísero egoísmo de los caudillos subalternos.

El único que merece nuestra entusiasta adhesión es el general Sandino, porque el general Sandino representa, con sus heroicos guerrilleros, la reacción popular de nuestra América contra las oligarquías infidentes y la resistencia de nuestro conjunto contra el imperialismo anglosajón.» ${ }^{45}$

En lo que refiere a Falcón, su homenaje vino en forma de carta pública en la que otorgaría al nicaragüense un carácter mítico, categorizándolo como «el primer héroe de nuestra epopeya». Es de reseñar que, tras este adjetivo, el peruano plasmaría un concepto de raza emparentado con el del hispanoamericanismo pero con algunos visos que, en detalle, parecieran apuntar a un enfoque más acorde con su doctrinario:

«... le ruego iluminar constantemente su espíritu con la idea de la integridad de nuestra raza. Usted no está luchando por la libertad de Nica-

${ }^{43}$ Hablamos de alegatos de sus adeptos, de ahí la generalización frente a los diversas coyunturas y sentimientos que pudiera inspirar el nicaragüense en los diferentes países o a sus elites políticas.

44 Manuel Ugarte, «El Congreso panamericano de La Habana»; en La Rábida: Revista Colombina Iberoamericana, Junio 1928, p. 11.

45 Manuel Ugarte, «Nicaragua - Manuel Ugarte y los estudiantes americanos en Europa»; en La Rábida: Revista Colombina Iberoamericana, Julio 1928, p. 11. 
ragua, sino por la libertad de todos los pueblos hispánicos, de todos los pueblos de nuestra sangre, nuestro espíritu y nuestra lengua, porque todos ellos, de un modo o de otro son pueblos irredentos [...]

Ustde [sic] es el primer héroe de nuestra epopeya, de nuestra mitología. No importa si no vence ahora mismo a los monstruos del Norte. Usted los vencerá al fin. La historia de nuestra redención comenzará a contarse, años adelantes [sic], con estas palabras: «A los treinta y tres años, el capitán Sandino, guiado por la mano invisible de Cristo, porque venía a defender nuestra fé [sic] en la igualdad de los hombres, a satisfacer nuestra justicia y a redimirnos de todas las opresiones, salió con sus hombres de las selvas musicales de Nicaragua». Y la historia de nuestra redención será la historia de la gran comunidad hispánica libre.» 46

La carta venía acompañada de una imagen de Sandino en cuyo epígrafe rezaba «Los rasgos del héroe revelan que Augusto Sandino lleva la vida en la libertad de su Patria y su Raza», aunando en el conjunto elementos propios del discurso hispanoamericanista - como «Patria», «Raza» o esa mención providencialista a «la mano invisible de Cristo»con otros perfectamente integrables en la dialéctica de izquierdas, léase la fe en la igualdad de los hombres o la redención de todas las opresiones.

El interés por Sandino fue creciendo con el paso de los meses. La rumorología, las noticias y contrainformaciones sobre sus avances y retrocesos, hicieron de su nombre un habitual en los medios. Periódicos hubo, como el Heraldo de Madrid, que designarían un enviado especial al efecto: Miguel V. Capuz ${ }^{47}$. Otros diarios aprovecharían el testimonio de corresponsales extranjeros para conocer más de cerca la figura del guerrillero, como el Heraldo de Madrid, con un especial firmado por el norteamericano Harry Stevenson; o El Sol, que publicaría los artículos de Carleton Beals sobre Sandino y su vida en las montañas. Beals fue el único periodista que llegaría a contactar directamente con él durante el conflicto $^{48}$, siendo publicado el resultado de sus encuentros en la neoyorquina The Nation. El impacto de sus reportajes sería tal que, poco tiempo des-

46 César Falcón, «Mi Capitán...»; en La Rábida: Revista Colombina Iberoamericana, Mayo 1928, p. 12.

47 Tal y como anunciaría en su contraportada del 8 de febrero.

48 Los otros dos periodistas que llegarían a tener un contacto directo con Sandino serían el vasco Ramón Belausteguigoitía y el nicaragüense José Román, pero no sería hasta 1933, es decir, una vez firmada la paz y con los marines fuera del país. 
pués de haber visto la luz en los Estados Unidos, fue que El Sol decidió editar una traducción de los mismos bajo el título «Con Sandino en Nicaragua ${ }^{49}$. Merece la pena recalcar un extracto de la última conversación que mantuvieron y que el periodista utilizó para introducir su reportaje:

«Su última pregunta al separarnos fue:

- ¿Cree todavía que somos unos bandidos?

- Tiene usted tanto de bandido como Mr. Coolidge de bolchevique - contesté.» ${ }^{50}$

La respuesta de Beals rebatiría las recurrentes acusaciones de bandolerismo con las que los medios afines a Washington justificaban su presencia en Nicaragua. En cierto modo, el propio Beals representaría a esos sectores intelectuales - como la Liga Antiimperialista norteamericanaque, pese a su origen, censurarían el expansionismo de su gobierno y sus excesos, organizando campañas de desigual impacto en busca de una mayor repercusión ${ }^{51}$. Lo que resulta innegable es que el trabajo de Beals descubrió al público estadounidense una imagen de Sandino desconocida para la inmensa mayoría y, de manera indirecta, reforzó la perspectiva heroica que sobre éste se había forjado en el imaginario hispanoamericano.

Las variantes que se desarrollarían de tal imagen se fueron perfilando progresivamente dependiendo del contexto y del medio que la abordase. En realidad, casi podría hacerse una retrospectiva - si no diaria, sí semanal - en la que se apreciaría la evolución de Sandino como icono, sobre todo durante su periplo guerrillero y tras su asesinato. Conforme a ello, un punto concurrente, y de partida, sería la representación de Sandino como patriota, proyectando su lucha como la reacción de un hombre leal a su país sin más ambición que garantizar su independencia y soberanía. Dicho retrato sería perceptible tanto en periódicos conservadores, como el

49 The Nation publicó los reportajes de Beals entre el 22 de febrero y el 12 de abril de 1928, saliendo el primero de ellos en El Sol el 22 de abril de ese mismo año.

${ }^{50}$ Carleton Beals, «Con Sandino en Nicaragua - Hacia la frontera nicaragüense»; en El Sol, 22 de abril de 1928, p. 3.

${ }^{51}$ Una de ellas consistiría en la venta de sellos reprobatorios con la inscripción «Protesta contra la actuación de la Marina en Nicaragua» para ser pegados en el reverso de las cartas. La medida fue impedida por el servicio postal norteamericano, que amenazó con medidas judiciales en caso de que el sello fuese puesto en circulación. De dicha polémica harían mención, entre otros, El Sol y La Libertad en sus ediciones del 15 de febrero de 1928. 
$A B C^{52}$; como en los liberales ${ }^{53}$ o en aquellos que - pese a la censura primorriverista - deslizaban un posicionamiento más izquierdista, como La Libertad:

«Reflexionad sobre el caso de Sandino. Un muchacho sin fortuna ni cultura, sólo impulsado por una emoción patriótica, de alta dignidad, se enfrenta con el mayor poder del mundo moderno, con Washington. Desafía al coloso y a todos los serviles que le rinden, como esclavos, la más abyecta sumisión.» ${ }^{54}$

Tal coincidencia no difuminaría las peculiaridades interpretativas que las distintas cabeceras harían del rebelde según su tendencia. En las de signo más tradicional, por ejemplo, serían usuales las menciones raciales ya apuntadas en el hispanoamericanismo conservador, mientras que en las de sello más progresista la lectura iría más dirigida a la glosa antiimperialista de liberación, vinculándola a los grandes principios democráticos e, incluso, revolucionarios. La diferencia es visible si careamos nue-

52 Dos ejemplos: «... el general Sandino no solo defiende una causa sagrada, cual es la de la independencia de su país, sino que se muestra desprendido y desprovisto de toda ambición personal». «La figura de Sandino»; en $A B C, 30$ de marzo de 1928, p. 12.

«El general Sandino, único que mantiene en alto la dignidad del país, quizá no mirando, no ya sus conveniencias prácticas propias, sino ni siquiera las de su Patria, pero velando por el honor nacional, que debe estar siempre por encima de las propiedades materiales». «Las próximas elecciones presidenciales en Nicaragua - Candidatos que irán a la lucha»; en $A B C, 29$ de junio de 1928, p. 12.

53 Ya fuese en editoriales o en artículos firmados por sus colaboradores. Max Grillo, por ejemplo, atribuiría a Sandino, por fuente indirecta, el siguiente testimonio: «... vaya a Europa y diga en París que el bandido Sandino no deshonra sus pequeñas victorias. Tengo prisioneros, entre ellos un oficial de alta graduación, por cuyo rescate me han ofrecido cinco mil dólares. Hambién [sic] me han ofrecido cincuenta mil porque haga la paz, como si el que severamente acepta la muerte pudiera pensar en el oro de los enemigos de su patria. Me cotizan como a cualquier Díaz». Max Grillo, «Figuras de epopeya - Augusto Sandino»; en El Sol, 19 de abril de 1928, p. 1.

«No hay que decir que, al defender esa posición [favorable a la presencia norteamericana], se califica a Sandino de aventurero vulgar y ambicioso, movido por estímulos subalternos.

No resulta, sin embargo, que la ambición sea el flaco de Sandino [...] César Augusto Sandino ese «aventurero vulgar y ambicioso», cada día encarna más a la Nicaragua que quiere ser libre». Benito Artigas Arpón, «En Nicaragua - Sandino, el Congreso y la intervención yanqui»; en $\mathrm{La}$ Voz, 21 de marzo de 1928, p. 3.

54 «Los hombres-símbolos - El general Sandino»; en La Libertad, 26 de abril de 1928, p. 3. 
vamente $A B C^{55}, L_{a} V_{o z}^{56}, E l S^{5} l^{57}$ y $L_{a}$ Libertad $^{58}$, pudiendo añadir al cuarteto - a fin de patentizar la visión libertaria - las referencias que de Sandino harían publicaciones como La Revista Blanca de la mano de Federica Montseny:

«... Sandino, emblema de independencia, de dignidad humana enfrentada contra el dominio y la anulación del ente hombre que representa Norteamérica [...] Si Sandino muere y la pequeña Nicaragua es devorada por el monstruo yanqui, el hombre habrá sufrido la más espantosa de las derrotas: habrá muerto como sensibilidad, pensamiento,

55 «... Augusto César Sandino, en quien están puestas las miradas de todos los defensores de los ideales raciales por personificarlos él en estos momentos, y que hasta el instante los ha defendido con toda dignidad y abnegación, conquistándose numerosas simpatías, incluso entre el propio pueblo norteamericano». «Lo que piensa del gesto de Sandino una gran poetisa»; en $A B C, 27$ de abril de 1928, pp. 11-13.

56 «A primera vista un paralelo entre Hatuey y Sandino ha de parecer arbitrario. Sobre todo si se piensa que Sandino procede de la raza de los conquistadores de América [...] La conquista de América, científicamente observada, se presenta como uno de esos grandes hechos biológicos en que una especie superior sustituye a otra, inferior o depauperada [...] Hoy toda América está civilizada, es consciente. Existirán matices de cultura y de educación política que coloquen a algunas naciones americanas en un estado de inferioridad respecto a la «nación mayor». Pero esas naciones menores poseen cualidades suficientes para regirse por si mismas, $\mathrm{y}$, al luchar pos su existencia autónoma, lo hacen - como Sandino - con las armas y las ideas del siglo Xx, no con las flechas y las supersticiones de Hatuey». Alberto Insúa, «El blanco Sandino y el indio Hatuey»; en La Voz, 28 de abril de 1928, p. 1.

57 «Los Estados Unidos permitirán que se escoja entre dos candidatos intervencionistas. Mientras no se salgan de esa pauta se les garantizará la libertad de elección. Para evitar los sufragios adversos es para lo que se envían tropas constantemente. Sandino y los suyos no representan un sector de la voluntad del país, aunque todo el país les ayude a combatir contra las tropas de ocupación [...] Como se ve, los Estados Unidos imponen por las armas la libertad de pronunciarse en favor de la política de Washington». «Las elecciones en Nicaragua»; en El Sol, 21 de agosto de 1928, p. 1.

58 Tomando como fuente una carta enviada a Froylán Turcios «¿Por qué este hombre broncíneo - de cuerpo y alma - se lanzó a una lucha increíblemente desigual. Lo dice en su recio estilo: «Soy nicaragüense, y me enorgullezco que en mis venas circule, más que todo, la sangre india, que por atavismo encierra el misterio de ser patriota, leal y sincera [...] Soy artesano: mi ideal campa en un amplio horizonte de internacionalismo, lo cual representa el derecho de ser libre y de justicia, aunque para alcanzarlo sea necesario constituirlo a base de sangre» [...] Así habla el símbolo de la América que quiere ser soberana». Camilo Barcia Trelles, «Medallón nicaragüense - El General Augusto Sandino»; en La Libertad, 21 de abril de 1928, p. 1. 
conciencia, ideal, aspiraciones, impulso evolutivo, poesía, individualidad libre $[. ..] \mathrm{El}$ fin del mundo, en una palabra.» ${ }^{59}$

Merece la pena subrayar las diferencias subyacentes en artículos como los de Insúa y Camilo Barcia en cuanto a la cuestión étnica, vindicando en el origen - bien español, bien indígena- dos opiniones divergentes sobre el pasado, su interpretación y los efectos desprendidos del mismo en alguien como Sandino. No obstante, desde otro enfoque, el texto de Barcia ya mostraría una intencionalidad ideológica más acusada en lo tocante a resaltar la condición artesana del guerrillero y una visión internacionalista que - en sus afanes de libertad, justicia y esa América soberana evocada - bien podría glosar el espíritu antiimperialista y obrero de la izquierda española.

Este último aspecto se haría más perceptible tras el asesinato de Sandino en 1934. Para entonces el contexto político español había cambiado sustancialmente, con una II República que mermaría de un modo notable el ascendiente del hispanoamericanismo tradicional e intentó rebajar el influjo de la prensa controlada por sus opositores ${ }^{60}$. Esta tensión se trasladaría al entorno mediático, con diarios anteriormente críticos con la monarquía como El Sol que, tras sufrir cambios en su accionariado, verían alteradas sus líneas editoriales, lo que afectaría seriamente a su reputación ${ }^{61}$. Aun así, para el tema que nos concierne, las noticias publicadas sobre la muerte de Sandino por las redacciones de sesgo conservador $-\mathrm{y}$ aun por algunas de rebajado signo progresista - irían en consonancia a lo publicado en vida del guerrillero, insistiendo en silogismos similares a los del hispanoamericanismo tradicional:

«Algún día se conocerá con la minuciosidad requerida todo el desarrollo de la guerra desigual mantenida por el héroe de Las Segovias, y

59 Federica Montseny, «Visión retrospectiva - Un mundo en crisis»; en La Revista Blanca, 15 de julio de 1928, p. 74.

60 Sobre todo a través de la Ley de Defensa de la República, aprobada el 20 de octubre de 1931, y la posterior Ley de Orden Público, promulgada el 28 de octubre de 1933. Seoane; Saiz, 2008: 403-407.

${ }^{61}$ Un proceso parecido sufriría también el diario La Voz. En el caso de El Sol tendríamos que hablar de un vaivén de antimonárquico a monárquico y, tras la proclamación de la República, a republicano «de orden», que dejaría seriamente dañada su credibilidad ante determinados sectores. De tales vaivenes devendría la salida de $\mathrm{El} \mathrm{Sol} \mathrm{incluso} \mathrm{de} \mathrm{su} \mathrm{funda-}$ dor, Nicolás María de Urgoiti, quien se embarcaría en otras aventuras editoriales de éxito incierto pero más afines con su republicanismo crítico, como Crisol o Luz. Más información en Seoane; Saiz, 2008, 411-423. 
entonces el mundo hispano se dará cuenta de las condiciones excepcionales en que la lucha se mantuvo y el temple magnífico del mantenedor de esta gesta, característica de nuestra raza, asesinado ahora traidoramente por compatriotas suyos.» ${ }^{62}$

$$
\text { * } \quad * \quad *
$$

«El "Pequeño Sandino", que después de haber arrostrado los peligros de una lucha quijotesca, acaba de caer víctima de una villanía, era un auténtico ejemplar de la raza ibérica, el prototipo del guerrillero. Es decir, un espíritu independiente, movido por la fe en un ideal y empujado por el heroísmo indisciplinado [...] Sandino, como los libertadores Bolívar y San Martín, es una gloria española, porque en toda su aventura resplandecieron las virtudes raciales llevadas al Nuevo Mundo por conquistadores y colonizadores.» ${ }^{63}$

$$
* \quad * \quad *
$$

«Sandino encarnaba en sí mismo una virtud latente en los pueblos hispánicos, tanto de Europa como de América: la virtud de producir en el momento preciso el hombre necesario. Todas las fuerzas secretas de la raza aparecen sublimadas en un hombre, y aquel hombre salva a su gente. Matar a un hombre así es atentar contra el espíritu de la raza ¿Quién se atreve a matarlo? Si: puede comprenderse el que los Estados Unidos tuvieran interés en suprimir al general Sandino, testimonio vivo de que el Derecho puede resistir a la Fuerza, y un Pueblo libre a un Imperio esclavizador. Puede comprenderse, aunque a nosotros, «hombres de Hispania fecunda», nos cueste trabajo comprenderlo. Nosotros obramos de otro modo.» ${ }^{64}$

$$
\text { * } \quad * \quad *
$$

«El mundo entero conoció la gesta heroica de este bravo caudillo hispanoamericano, El Empecinado de América, como le ha llamado con razón Dionisio Pérez [...] Firme e inquebrantable en su propósito de

62 José Gutiérrez-Rave, «Política Hispanoamericana - Problemas actuales»; en $A B C$, 21 de abril de 1934, p. 15.

63 «En Nicaragua - El general Sandino, su hermano y sus ayudantes, asesinados - Un ejemplar de la Raza»; en La Nación, 23 de febrero de 1934, p. 6.

${ }^{64}$ Rufino Blanco Fombona, «El asesinato de Sandino y los Estados Unidos»; en La Voz, 12 de julio de 1934, p. 1. 
defender la raza de las abyecciones a que la sometía el invasor imperialista, se lanzó a la más desigual y titánica lucha de los modernos tiempos [...] Los pueblos del orbe, sin distinción de raza, le admiraban.» ${ }^{65}$

Frente a ellos, las publicaciones de talante más obrero y radical surgidas al albur de la II República ampliarían la imagen gestada durante el Directorio por la prensa progresista, reafirmando a Sandino como un icono eminentemente antiimperialista. Con ello, las coincidencias con los conservadores en torno a Sandino como símbolo - por ejemplo, las comparaciones históricas como marchamo de legado y continuidad racial - se verían complementadas con acusaciones a los Estados Unidos como perpetradores intelectuales del crimen, de manera tal que, el tono lastimero y un tanto escéptico del ahora moderado $\mathrm{El} \mathrm{Sol}$, se vería rematado por el más batallador de La Tierra o Luz, en los que el nicaragüense sería retratado como ejemplo de desprendimiento, integridad, compromiso y, ante todo, de resolución ante las arbitrariedades del poder. Un poder que, en sus páginas, quedaría encarnado en Wall Street y el materialismo norteamericano.

«... el general Augusto César Sandino es asesinado al año casi de reintegrarse de lleno a las pacíficas actividades de una vida sin emociones violentas, sin sobresaltos, sin grandes responsabilidades, tan desusadas para el aguerrido soldado que llegó a ser considerado como una de las grandes figuras de la historia hispanoamericana [...] los caprichos del Destino le robaron la gloria de haber caído como un héroe cuando capitaneaba los cuadros mal nutridos y mal pertrechados de los patriotas nicaragüenses contra el grotesco mecanismo del imperialismo yanqui [...] cae Sandino víctima de la venganza o de la envidia, cuando ya la aureola gloriosa de 1927 y 1928 se había esfumado totalmente.»66

«Sandino era un símbolo vivo de la América hispana que se yergue altanera ante el imperialismo anglosajón: la personificación de las ansias de libertad de los pueblos de sangre íbera [...] Y Sandino, como

65 «El asesinato del general Sandino, el «Empecinado» de América»; en Revista Hispanoamericana de Ciencias, Letras y Artes, Febrero-Marzo 1934, pp. 62-63.

66 «Sandino, asesinado - Caudillo y juguete del Destino»; en El Sol, 23 de febrero de 1934, p. 1 . 
tantos otros héroes de la independencia americana, acaba de ser asesinado. Unos soldados de la Guardia Nacional, unos soldados nicaragüenses a las órdenes de la plutocracia de Wall Street, han terminado cobardemente, a traición, con la vida del hombre que supo enarbolar la bandera de la independencia nacional [...] Como Viriato asesinado por guerrilleros lusitanos, Sandino ha sido muerto por soldados nicaragüenses. ¡Buen precio habrán puesto a la cabeza del general! Aunque luego, cuando vayan a cobrar, reciban también por todo premio una frase histórica para enseñanza de confidentes y asesinos: "Wall Street no paga traidores...".

Pero Wall Street pagará. El servicio ha sido demasiado importante para no sentirse espléndido.» ${ }^{67}$

$$
* \quad * \quad *
$$

«Sandino es ya el "padresito" de Nicaragua. Unos con temor y otros con admiración y cariño, todos se hacen lenguas del nuevo Bolívar nicaragüense. [...] Sólo un pueblo le contempla con profundo rencor. Los Estados Unidos respiran por el Wall Street, que ya contaba con unos pozos petroleros en Nicaragua. Sandino es un contratiempo que hay que eliminar $[\ldots]$

Hoy, en los pozos petroleros de Nicaragua se ha alzado una bandera estrellada, que en un tiempo pretendió ser símbolo de la libertad. Todos los pozos de Nicaragua se han engalanado con farolillos verbeneros de Broadway. Ya no hay peligro. Ya el petróleo es libre. Ya ha muerto el tirano Sandino. ¡Las acciones de petróleos están en alza en Nueva York!»68

$$
\text { * } \quad * \quad *
$$

«Es el último romántico, el postrer caballero del ideal, de un ideal traducido en hechos y personificado en una individualidad. No discu-

67 «Wall Street, a la conquista del caucho - Sandino, el caudillo asesinado»; en La Tierra, 23 de febrero de 1934, p. 1. Es de referir que este periódico, si bien se situó desde sus inicios en una «línea de demagogia filoanarquista», estuvo financiado por personas totalmente alejadas de dicha ideología, caracterizándose por campañas desmesuradas que, con frecuencia, harían más el juego a la extrema derecha que a sus adláteres. En todo caso, $L a$ Tierra haría de tribuna antes y después de la fundación del diario CNT, siendo habitual que, en las interrupciones de este último, actuase de manera sustitutoria. Más información en Seoane; Saiz, 2008, 431-433,

68 Nicolás Martín Alonso, «El «padresito» de Nicaragua»; en Luz, 2 de marzo de 1934, p. 8 . 
tiremos si su ideal era muy amplio [...] Pero frente al industrialismo feroz de Yanquilandia, ante la anulación monstruosa del hombre, ante cuanto signifique de opresor, de sanguinario, de absorbente el espíritu americano, Sandino levantaba la bandera de la independencia individual, la afirmación del poder del hombre frente y en contra de esa máquina odiosa del Estado.» ${ }^{69}$

De los párrafos escogidos puede colegirse, de manera resumida, la concordancia elegiaca de los distintos rotativos pese a las diferencias doctrinales. Una afinidad paradójica, por cuanto confirmaba la adhesión pública que suscitaba Sandino a pesar de la polarización política en la que estaba sumiéndose el país. Pero también una constatación de cómo esa simultaneidad, esa devoción compartida por el nicaragüense, aun partiendo de un mismo punto, inspiraría lecturas disímiles según la ideología e intencionalidad de quien la plasmase.

\section{A modo de conclusión}

La coyuntura nacional e internacional no tardaría en sumir el recuerdo de Sandino en el olvido. La Guerra Civil Española y la posterior guerra mundial haría que su figura se viese desplazada a un plano secundario, no volviendo a sonar su nombre, salvo de manera casual, hasta 1961, año en que apareció el Frente Sandinista de Liberación Nacional como oposición activa contra la dictadura de su victimario, Anastasio Somoza.

El tiempo difuminaría la evocación de Sandino como icono conservador, restringiendo su memoria y reivindicación principalmente al izquierdismo. No cabe duda de que la consolidación del discurso descolonizador tras la Segunda Guerra Mundial y la identificación del antiimperialismo como premisa eminentemente izquierdista cubrió con un tupido velo las manifestaciones pretéritas provenientes, en este sentido, de sectores más tradicionales. Tampoco puede negarse que, lo que podía interpretarse como expresiones antiimperialistas de estos últimos, circunscribieron la crítica, por lo general, a los Estados Unidos, lo que denotaría no tanto una censura a un colonialismo al que no le hacían ascos - tal y como puede

${ }^{69}$ Federica Montseny, «Glosas: El último romántico»; en La Revista Blanca, 15 de marzo de 1934, p. 288. 
desprenderse de la política española coetánea en el norte de Áfricacomo un antiyanquismo fuertemente arraigado.

Tal sentimiento explicaría la importancia del contexto en la conformación de Sandino como icono genérico. No puede obviarse que los años en los que el nicaragüense despertó la atención de la opinión pública internacional coincidieron con un momento dulce del hispanoamericanismo tradicional español, muy favorecido por el régimen primorriverista. Al mismo tiempo, en el tablero mundial se confirmaba, por un lado, el desplazamiento de la hegemonía europea en beneficio de los Estados Unidos y, por otro, la ratificación de escenarios revolucionarios que cuestionarían, ideológica y políticamente, la lectura monoposibilista de la realidad y el poder.

Todos estos elementos confluyeron de manera muy particular en el marco hispanoamericano. Si hubo un continente en el que el expansionismo estadounidense mostró su faz más descarnada fue, precisamente, en el latinoamericano, sobre todo en Centroamérica y el Caribe ${ }^{70}$. Esto explicaría cómo la convergencia de doctrinas unitarias de distinto signo - como el hispanoamericanismo, el latinoamericanismo, el indoamericanismo o el panamericanismo - incluiría una relación más o menos intensa con el pujante antiimperialismo, siendo ésta una perspectiva habitual conforme Washington emprendió nuevas injerencias políticas, económicas o militares al sur de sus fronteras.

En España había un extendido sentimiento antiyanquista que acabó por eclosionar a raíz de la Guerra de 1898. Fue a partir de ésta que todos los estereotipos y prejuicios antiestadounidenses se intensificaron, visualizándose en el seguimiento crítico que la prensa peninsular llevaría a cabo de las distintas intervenciones de los Estados Unidos en la América Hispana. Las críticas aunarían el sentimiento unitarista del hispanoamericanismo español con una censura diáfana al intervencionismo norteamericano, sumando a la reivindicación permanente del legado hispano frente al peligro yanquinizante la exaltación de quienes, con mayor o menor fortuna, encarnarían la oposición a los planes de Washington.

A este respecto, Sandino resultaría paradigmático. Su actitud, decisión y patriotismo alimentaron un relato que, junto a sus éxitos militares, colectivizaría como alegato, a escala continental, la reivindicación de la mente.

70 Sin olvidar, lógicamente, su actuación en Filipinas, tal y como apuntamos anterior- 
soberanía propia; la denuncia de los gobiernos cómplices y la primacía de los intereses nacionales sobre los foráneos. Su condición guerrillera facilitaría, además, el engarce de sus proezas como parte de una tradición militar típicamente española de la que el nicaragüense formaría parte como legatario. Dicho entronque sería visible tanto en los medios conservadores como progresistas, si bien con una mayor insistencia por parte de los primeros en línea con conceptos habituales de su discurso como la Raza, de ahí la vinculación de Sandino dentro de su narrativa con figuras históricas como Viriato o El Empecinado.

La convergencia en esa lectura «parahistórica» del pasado guerrillero no supondría una coincidencia absoluta entre las partes. Cierto es que la censura impuesta por Primo de Rivera tampoco dejaría un gran margen a los opositores al régimen como para esbozar una imagen de Sandino más acorde a su ideología. Sin embargo, el momento empujaría a ello. Las críticas al materialismo norteamericano formaban parte del argumentario hispanoamericanista, pero no así el enfoque obrerista, más propio de la izquierda y reforzado tras la revolución bolchevique. Tampoco puede decirse que sucesos como la ejecución de Sacco y Vanzetti, en 1927, mejorasen precisamente la imagen de los Estados Unidos dentro del movimiento obrero, sobre todo entre los círculos anarquistas ${ }^{71}$. A ello habría que añadirle la corriente de solidaridad que suscitaría el expansionismo estadounidense con sus intervenciones en América, avivando el sentimiento antiimperialista de la intelectualidad liberal y proletaria al punto de naturalizar la resistencia contra el coloso yanqui como parte de su dialéctica.

Es ahí donde se perfilarían las mayores diferencias en la definición de Sandino como icono. Así, aun tomando como referencia de contraste los mismos personajes históricos, la comparación entre éstos y el nicaragüense acabaría derivando hacia planos distintos según la cabecera que la plantease. O, dicho de otro modo, si en los medios conservadores la equiparación de Sandino y Bolívar tendería a desembocar en exaltaciones sobre la Raza y sus valores, en sus opuestos, por el contrario, se transmutaría en críticas al materialismo norteamericano y su política exterior; o en el resalte del centroamericano como artesano u obrero; o en vindicaciones en favor de la dignidad de los pueblos hispanoamericanos y sus derechos. No es que con ello se niegue cierto seguimiento de la progresía española - o, al menos, de parte de ella - a los axiomas hispanoamericanistas,

71 Fernández, 2012, 115. 
pero no de un modo tan determinante como haría la intelectualidad conservadora ni, evidentemente, con los mismos propósitos.

En resumen, el cotejo de lo publicado por los distintos medios evidencia las coincidencias $-\mathrm{y}$, aun de manera tenue, las divergenciasexistentes en la prensa española en torno a la figura de Augusto César Sandino. Lo mismo en cuanto a los periodos en que se hicieron más ostensibles los argumentos de unos y otros: más patentes en los diarios conservadores bajo Primo de Rivera; más notorios en los de tendencia progresista con la II República. Con todo, sí parece probada la adecuación de un personaje como Sandino a los requerimientos de las diversas facciones; al igual que la paradoja de que, partiendo de lugares comunes, ideologías contrapuestas convirtieran a un mismo hombre en emblema de sus distintos postulados.

\section{Fuentes}

ABC (Madrid: 1928-1934).

El Imparcial (Madrid: 1927-1933).

El Sol (Madrid: 1927-1934).

Heraldo de Madrid (Madrid: 1928-1934).

La Época (Madrid: 1927-1934).

La Libertad (Madrid: 1927-1934).

La Nación (Madrid: 1934).

La Rábida: Revista Colombina Iberoamericana (Huelva: 1928).

La Revista Blanca (Barcelona: 1928-1934).

La Tierra (Madrid: 1934).

La Voz (Madrid: 1927-1934).

Luz (Madrid: 1934).

Revista Hispanoamericana de Ciencias, Letras y Artes (Madrid: 1934).

\section{Webgrafía}

ABC Hemeroteca. URL: http://hemeroteca.abc.es/

Biblioteca Nacional de España. Hemeroteca Digital. URL: http://www.bne.es/ es/Catalogos/HemerotecaDigital/

Biblioteca Virtual de Prensa Histórica. URL: http://prensahistorica.mcu.es/

Universidad Internacional de Andalucía. Repositorio abierto. Fondo Histórico

Digital de La Rábida. URL: http://dspace.unia.es/handle/10334/105 


\section{Bibliografía}

AndrÉs GARCÍA, Manuel, «De la "Patria Grande" a la "Madre Patria": Manuel Ugarte y el hispanoamericanismo español (1900-1930)», Revista de Indias, Vol. LXXIV, n. ${ }^{\circ}$ 261, 2014, pp. 591-622.

ANDRÉs GARCÍA, Manuel, «Sandino en La Habana: la VI Conferencia Internacional Americana a ojos de la prensa e intelectualidad españolas», Revista Complutense de Historia de América, n. ${ }^{\circ}$ 43, 2017, pp. 285-306.

AzCÁRATE, Manuel, «La percepción española de los Estados Unidos», Leviatán: Revista de Pensamiento Socialista, II Época, n. ${ }^{\circ} 33$, Otoño 1988, pp. 5-18.

BArrios, M.A. (2007) El latinoamericanismo en el pensamiento político de Manuel Ugarte, Buenos Aires: Biblos.

FERnÁNDEZ DE Miguel, Daniel, El enemigo yanqui. Las raíces conservadoras del antiamericanismo español, Madrid, Genueve Ediciones, 2012.

FunEs, José Antonio, «Froylán Turcios y la campaña a favor de Sandino en la revista Ariel (1925-1928)», Cuadernos Americanos, Vol. 3, n. ${ }^{\circ}$ 133, 2010, pp. 181-208.

Gracia PÉRez, Felipe, Hijos de la Madre Patria. El hispanoamericanismo en la construcción de la identidad nacional colombiana durante la Regeneración (1878-1900), Zaragoza, Institución Fernando el Católico (CSIC), 2011.

GranAdos, Aimer, Debates sobre España: el hispanoamericanismo en México a fines del siglo XIX, México D.F., El Colegio de México, Universidad Autónoma Metropolitana, Unidad Cuajimalpa, 2010.

Hilton, Sylvia L., «La «nueva» Doctrina Monroe de 1895 y sus implicaciones para el Caribe español: algunas interpretaciones coetáneas españolas»; en Anuario de Estudios Americanos, Tomo IV, n. ${ }^{\circ}$ 1, 1998, pp. 125-151.

León AguinagA, Pablo, «La historiografía española y las relaciones con los Estados Unidos de América: las consecuencias del Pacto de Madrid y la Transición», Cuadernos de Historia Contemporánea, n. ${ }^{\circ}$ 34, 2012, pp. 357-370.

Martí i Puig, Salvador, Rebeliones y Democracia. Itinerarios políticos en América Central, Barcelona, Bellaterra, 2004.

MonTERo JiméneZ, José Antonio, «Ideología y pragmatismo. Los diplomáticos estadounidenses y la España de los años veinte»; en Circunstancia: Revista de Ciencias Sociales del Instituto Universitario de Investigación Ortega y Gasset, n. ${ }^{\circ} 22,2010$.

Montero Jiménez, José Antonio, El despertar de la gran potencia. Las relaciones entre España y los Estados Unidos (1898-1930), Madrid, Biblioteca Nueva, 2011.

NiÑo, Antonio, «50 años de relaciones entre España y Estados Unidos», Cuadernos de Historia Contemporánea, n. ${ }^{\circ}$ 25, 2003, pp. 9-33.

Pita GonZÁlez, Alexandra, La Unión Latino Americana y el boletín Renovación. Redes intelectuales y revistas culturales en la década de 1920, México DF, El Colegio de México, 2009. 
Quijano, Carlos, Nicaragua, ensayo sobre el imperialismo de los Estados Unidos, 1909-1927, Managua, Vanguardia, 1987.

SANDino, Walter C., El libro de Sandino. El bandolerismo de Sandino en Nicaragua, Managua, INPASA, 2009.

SElser, Gregorio, Sandino, General de Hombres Libres, Buenos Aires, Abril, 1984.

SELSER, Gregorio, Cronología de las intervenciones extranjeras en América Latina. Tomo I (1776-1848), México DF, CEIICH-UNAM, 2010a.

SElSER, Gregorio, Cronología de las intervenciones extranjeras en América Latina. Tomo II (1849-1898), México DF, CEIICH-UNAM, 2010b.

Seodne, María Cruz; SAIz, María Dolores, Historia del periodismo en España. Tomo 3. El siglo XX: 1898-1936, Madrid, Alianza Editorial, 1998.

Sepúlveda MuÑoz, Isidro, Comunidad Cultural e Hispano-Americanismo. Madrid, UNED, 1994.

SePúlveda Muñoz, Isidro, El sueño de la Madre Patria: hispanoamericanismo y nacionalismo, Madrid, Marcial Pons Historia, 2005.

\section{Financiación}

Este trabajo forma parte del proyecto $\mathrm{I}+\mathrm{D}+\mathrm{i}$ «España como escenario. Diplomacia y acción cultural en la formación de redes transnacionales con América (1914-1945)» (PGC2018-094231-B-I00), financiado por el Ministerio de Ciencia, Innovación y Universidades en la convocatoria de 2018.

\section{Datos del autor}

Manuel Andrés García es Doctor en Historia de América (Universidad de Sevilla, 2004), Máster en Historia Latinoamericana (Universidad Internacional de Andalucía, 1997) y Licenciado en Geografía e Historia (Universidad de Zaragoza, 1992).

Ha publicado monografías como: La construcción del poder: Estado, $\mathrm{Na-}$ ción e Identidades. La construcción del Estado nacional en Perú y la marginación política indígena (siglo XIX) (Zaragoza: IFC, 2002); De Peruanos e Indios. La figura del indígena en la intelectualidad y política criollas (siglos XVII-XIX) (Sevilla: UNIA, 2007); Indigenismo, Izquierda, Indio. Perú, 1900-1930 (Sevilla: UNIA, 2009). Mantiene como líneas de investigación fundamentales: Hispanoamericanismo; Antiimperialismo; Indigenismo; Izquierda Latinoamericana; Relaciones Culturales España-Latinoamérica; Estado-Nación y políticas de exclusión. 